[3] Transition to Sustainable Buildings: Strategies and Opportunities to 2050, Paris: International Energy Agency, 2013. $290 \mathrm{p}$.

[4] 2019 Global Status Report for Buildings and Construction. Global Alliance for Buildings and Constructions. [Online]. Available: https://globalabc.org/resources/publications/2019-global-status-report-buildings-and-construction (Accessed: Feb. 20, 2020).

[5] Pro enerhetychnu efektyvnist budivel: Zakon Ukrainy vid 22.06.2017 № 2118-VIII. Zakonodavstvo Ukrainy. [Online]. Available: https://zakon.rada.gov.ua/laws/show/2118-19 (Accessed: Feb. 20, 2020) .

[6] Pro zatverdzhennia pereliku budivel promyslovoho ta silskohospodarskoho pryznachennia, obiektiv enerhetyky, transportu, zviazku ta oborony, skladskykh prymishchen, na yaki ne poshyriuiutsia minimalni vymohy do enerhetychnoi efektyvnosti budivel ta yaki ne pidliahaiut sertyfikatsii enerhetychnoi efektyvnosti budivel: Postanova Kabinetu Ministriv Ukrainy vid 11.04.2018 № 265-2018-p. Zakonodavstvo Ukrainy. [Online]. Available: https://zakon.rada.gov.ua/laws/show/265-2018-\%D0\%BF (Accessed: Feb. 20, 2020).

[7] Mihai, M., Tanasiev, V., Dinca, C., Badea, A., and Vidu, R. "Passive house analysis in terms of energy performance," Energy and Buildings, vol. 144, pp. 74 - 86, June 2017, doi: 10.1016/j.enbuild.2017.03.025.

[8] Passive House Institute, Criteria for the Passive House, EnerPHit and PHI Low Energy Building Standard. Passivhaus Institut. [Online]. Available: https://passiv.de/downloads/03 building_criteria_en.pdf (Accessed: Feb. 20, 2020).

[9] Carutasiu, M.-B., Tanasiev, V., Ionescu, C., Danu, A., Necula, H., \& Badea, A. "Reducing energy consumption in low energy buildings through implementation of a policy system used in automated heating systems," Energy and Buildings, vol. 94, pp. 227 - 239, May 2015, doi; 10.1016/j.enbuild.2015.03.008.

[10] Pro zatverdzhennia Metodyky vyznachennia enerhetychnoi efektyvnosti budivel: Nakaz Ministerstva rehionalnoho rozvytku, budivnytstva ta zhytlovo-komunalnoho hospodarstva Ukrayiny vid 11.07.2018 № z0822-18. Zakonodavstvo Ukrainy. [Online]. Available: https://zakon.rada.gov.ua/laws/show/z0822-18 (Accessed: Feb. 20, 2020).

[11] DSTU B EN 15232:2011. Enerhoefektyvnist budivel. Vplyv avtomatyzatsii, monitorynhu ta upravlinnia budivliamy (EN 15232:2007, IDT). Kyiv: Minrehion Ukrainy, 2012.

[12] Chen, S., Zhang, G., Xia, X., Setunge, S., \& Shi, L. "A review of internal and external influencing factors on energy efficiency design of buildings," Energy and Buildings, vol. 216, June 2020, Art. no. 109944, doi: 10.1016/j.enbuild.2020.109944.

[13] Fabi, V., Barthelmes, V. M., Schweiker, M., \& Corgnati, S. P. "Insights into the effects of occupant behaviour lifestyles and building automation on building energy use," Energy Procedia, vol. 140, pp. 48 - 56, Dec. 2017, doi; 10.1016/j.egypro.2017.11.122.

[14] Iweka, O., Liu, S., Shukla, A., \& Yan, D. "Energy and behaviour at home: A review of intervention methods and practices," Energy Research \& Social Science, vol. 57, Nov. 2019, Art. no. 101238, doi: 10.1016/j.erss.2019.101238.

\title{
ЗАСТОСУВАННЯ КРИТЕРІЇВ ПОГЛИБЛЕНОГО ЕКСЕРГЕТИЧНОГО АНАЛІЗУ ДЛЯ ОБГРУНТУВАННЯ РІШЕНЬ З ПДВИЩЕННЯ ЕНЕРГЕТИЧНОЇ ЕФЕКТИВНОСТІ ТЕПЛОНАСОСНОЇ УСТАНОВКИ НА СТІЧНИХ ВОДАХ
}

\author{
Некрашевич О.В. ${ }^{1}$, Волощук В.А. ${ }^{2}$, Ковриго Ю.М. ${ }^{3}$
}

Національний технічний університет України «Київський політехнічний інститут імені Ігоря Сікорського», м. Київ, Україна

ORCID: ${ }^{1}$ https://orcid.org/0000-0003-2263-3549, ${ }^{2}$ https://orcid.org/0000-0003-0687-8968,

${ }^{3}$ https://orcid.org/0000-0002-2928-1905

E-mail: ${ }^{1}$ olena.nekrashevych@gmail.com, ${ }^{2}$ vl.volodya@gmail.com, ${ }^{3}$ yukovrygo@gmail.com

Copyright (C) 2020 by author and the journal "Automation of technological and business - processes.

This work is licensed under the Creative Commons Attribution International License (CC BY).

http://creativecommons.org/licanses/by/4.0

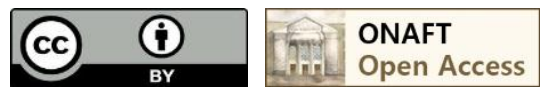

DOI: https://doi.org/10.15673/atbp.v12i2.1805 
http://www.atbp.onaft.edu.ua/

Анотація. В роботі на основі критеріїв поглибленого ексергетичного аналізу визначені місия, значення та причини термодинамічних втрат у теплонасосній установиі на стічних водах у складі системи теплозабезпечення будинку. Визначено, щзо у компресорі 76 \% деструкції ексергії, яку можна уникнути, залежить від термодинамічної досконалості інших елементів. Всі 100 \% деструкиї ексергії, щзо можна уникнути у дросельному вентилі, залежать від необоротностей в інших елементах. 90...97\% деструкиї ексергії, яку можна уникнути у конденсаторі, випарнику та проміжному теплообміннику залежать від термодинамічної досконалості ияих же елементів. Найбільше значення сезонної деструкиї ексергії, щзо можна позбутися у теплонасосній установиі за рахунок термодинамічного удосконалення $k$-го компонента, зосереджене у теплообміннику проміжного контуру $i$ становить близько $40 \%$. Випарник та конденсатор мають менші можливості з точки зору зниження деструкиї ексергї̈ у теплонасосній установиі (відповідно 29 та 24 \%). У компресорі такі можливості незначні. Відповідно, з метою підвищення енергетичної ефективності такої установки, необхідно у першу чергу знижувати необоротності у проміжному теплообміннику шляхом зменшення у ньому температурного напору. Отримані висновки підтверджуються шляхом розрахунку сезонного споживання електроенергії для заданого сезонного виробництва теплової енергї у різних варіантах удосконалення теплонасосної установки. Показано, щуо саме удосконалення проміжного теплообмінника забезпечує найбільше (до 12\%) зниження сезонного споживання електроенергії.

Abstract. On the base of criteria of advanced exergetic analysis location, magnitude and causes of thermodynamic inefficiencies are identified within a wastewater source heat pump system providing space heating. It is shown that for the investigated conditions, the biggest part (76 \%) of exergy destruction in the compressor and all exergy destructions in throttling valve can be avoided by reducing irreversibilities in the remaining components of the system. $90 . . .97 \%$ of exergy destructions, which can be avoided in the condenser, evaporator and the wastewater heat exchanger, are mainly caused by irreversibilities within these components. The biggest part (40\%) of avoidable exergy destruction in the heat pump is due to thermodynamic inefficiencies (caused by temperature difference) in the wastewater heat exchanger. The condenser and the evaporator have fewer possibilities (respectively 29 and $24 \%$ ) for improving exergy efficiency of the system. The compressor has the last and minor priority for decreasing irreversibilities. According to the data obtained, in order to improve the energy efficiency of such system irreversibility within wastewater heat exchanger should be of the highest priority to decrease. For this case the temperature difference within this component should be decrease. The obtained conclusions are confirmed by calculating seasonal electricity consumption of different cases of the heat pump improvement. It is shown that enhancement wastewater heat exchanger provides the highest (up to 12\%) reduction of seasonal electricity consumption.

Ключові слова: ключові показники енергетичної ефективності, поглиблений ексергетичний аналіз, деструкція ексергії, теплонасосна установка на стічних водах, теплозабезпечення будинку

Keywords: Key energy efficiency indicators, advanced exergetic analysis, exergy destruction, wastewater source heat pump, space heating

\section{Вступ}

Теплонасосні установки (ТНУ) є одними із найбільш перспективних технологій в теперішній час для цілого ряду сфер. Особливе місце належить теплонасосним системам, що використовують низькопотенційну енергію стічних вод. Завдяки відносно вищим температурам низькопотенційного джерела такі системи характеризуються вищою енергетичною ефективністю. 3 іншої сторони дані ТНУ є технологічно складнішими і дорожчими.

В існуючій науковій та особливо інженерній практиці для оцінювання енергетичної ефективності ТНУ використовують так званий коефіцієнт трансформації:

$$
C O P_{H P}=\frac{\dot{Q}_{H P}}{\dot{N}_{H P}}
$$

де $\dot{Q}_{H P}$ - теплова потужність ТНУ, Вт;

$\dot{N}_{H P}$ - електрична потужність, яка споживається для приводу ТНУ, Вт;

Разом 3 тим такий параметр характеризується певними недоліками [0]. По-перше, він інтегрально оцінює енергетичну ефективність установки. На основі даного критерію важко зрозуміти який елемент 3 його параметрами і на скільки впливають на споживання електричної енергії для заданої теплової потужності. По-друге, можна навести приклади, де застосування даного критерію призводить до помилкових висновків.

Коефіцієнт трансформації створений на основі суто енергетичного або ентальпійного балансу.

При обгрунтуванні параметрів та режимів роботи теплоенергетичних систем методи ексергетичного аналізу, що базуються на поєднанні Першого та Другого законів термодинаміки, характеризуються ширшими можливостями у порівнянні із методами енергетичного або ентальпійного аналізу, які в своїй основі використовують тільки Перший закон термодинаміки. 
http://www.atbp.onaft.edu.ua/

На відміну від енергетичного аналізу ексергетичний метод оцінювання пропонує критерії, які дають можливість визначити місцезнаходження, значення та джерела термодинамічних втрат в системі.

Новим етапом методології ексергетичного оцінювання є поглиблений ексергетичний аналіз, який розроблений представниками німецької школи прикладної термодинаміки [0 - 0]. Даний аналіз важливий з точки зору розширення можливостей ексергетичного підходу для прикладного використання.

Огляд літературних джерел показав, що методологія поглибленого ексергетичного аналізу реалізована, в основному, на прикладі холодильних машин або ТНУ промислового призначення, де розглядається тільки один режим роботи - номінальний [0- 0]. На основі детального аналізу існуючих робіт автори [0] приходять до висновку, що зовсім мало досліджень з ексергетичного оцінювання присвячено ТНУ на стічних водах. В роботі [0] наведені дані iз поглибленого ексергетичного аналізу ТНУ на стічних водах в складі системи теплозабезпечення будинку, але без урахування іiі термодинамічної взаємодії із теплообмінником, що призначений для передачі енергії стічних вод теплоносію проміжного контуру. Крім того, у випадку роботи ТНУ у складі системи теплозабезпечення будинку має місце мінливість його режимів роботи, що визначається впливом погодно-кліматичного чинника як всередині опалювального сезону, так і у багаторічному перерізі.

\section{Мета роботи}

Метою роботи є підвищення енергетичної ефективності ТНУ на стічних вод у складі системи теплозабезпечення будинку на основі застосування критеріїв поглибленого ексергетичного аналізу як ключових показників енергетичної ефективності.

\section{Викладення основного матеріалу}

В кожному елементі енергоперетворювальної системи можна позбутися тільки частини термодинамічних втрат. Через технологічні обмеження, які пов'язані, наприклад, із існуючими матеріалами, технологіями i/або вартістю матеріалів і виробничих процесів, максимальне значення ексергетичної ефективності k-го компонента не може бути збільшено при будь-яких інвестиціях. Частина деструкції ексергії, яка незалежно від досконалості компонента буде мати місце, називається неминучою, або та, якої позбутися неможна (англ. - unavoidable - UN). Iнша частина деструкції ексергії - та, якої можна позбутися (англ. - avoidable - AV) [0 - 0]:

$$
\dot{E}_{D, k}=\dot{E}_{D, k}^{A V}+\dot{E}_{D, k}^{U N}
$$

Отже, при удосконалені енергосистеми, зусилля повинні бути направлені саме на ту частину деструкції ексергії, якої можна позбутися.

Доведено, що деструкція ексергії в окремому елементі системи залежить від необоротностей як безпосередньо у самому елементі так і в інших елементів, що входять у систему [0 - 0]. В результаті була розроблена теорія розділення деструкції ексергії на внутрішньо залежну (англ. - endogenous - EN) та зовнішньо залежну (aнгл. - exodogenous - EX) $[0-0]$ :

$$
\dot{E}_{D, k}=\dot{E}_{D, k}^{E N}+\dot{E}_{D, k}^{E X}
$$

На основі отриманих значень внутрішньо та зовнішньо залежних частин деструкції ексергії можна розробити стратегію удосконалення системи $[0-0]$ :

- при $\dot{E}_{D, k}^{E N}>\dot{E}_{D, k}^{E X}$, необхідно зробити акцент на удосконалення даного компонента;

- при $\dot{E}_{D, k}^{E N}<\dot{E}_{D, k}^{E X}$, даний компонент може бути удосконалений «автоматично» за рахунок удосконалення інших компонентів системи або структурних змін системи.

- при $\dot{E}_{D, k}^{E N}=\dot{E}_{D, k}^{E X}$ варто перейти до аналізу інших елементів системи, оскільки удосконалення одного з інших елементів обов'язково вплине на значення деструкції ексергії в даному елементі, тобто призведе до перших двох випадків аналізу.

В результаті такого поділу деструкції ексергії з'явився так званий поглиблений ексергетичний аналіз [0 - 0]. Об'єднання цих чотирьох складових деструкції ексергії елемента системи забезпечило ії поділ на такі частини: внутрішньо залежну і ту, якої неможна позбутися $\dot{E}_{D, k}^{U N, E N}$ - не може бути усунута через існуючі технологічні обмеження даного елемента системи; зовнішньо залежну і ту, якої неможна позбутися $\dot{E}_{D, k}^{U N, E X}-$ не може бути усунута через існуючі технологічні обмеження інших елементів системи та даного структурного рішення; внутрішньо залежну і ту, якої можна позбутися $\dot{E}_{D, k}^{A V, E N}$ - може бути усунута за рахунок удосконалення даного елемента системи; зовнішньо залежну і ту, якої можна позбутися $\dot{E}_{D, k}^{A V, E X}$ - може бути усунута за рахунок удосконалення інших елементів системи та/або структурного рішення системи. 
Крім того, для кращого розуміння взаємного впливу компонентів системи, зовнішньо залежну деструкцію ексергії k-го компонента можна розділити за формулою [0]:

$$
\dot{E}_{D, k}^{E X}=\sum_{\substack{r=1 \\ r \neq k}}^{n-1} \dot{E}_{D, k}^{E X, r}+\dot{E}_{D, k}^{\text {mexo }}
$$

де $\dot{E}_{D, k}^{E X}, r$ - частина зовнішньо залежної деструкції ексергії в k-му компоненті, яка спричинена r-м компонентом;

$\dot{E}_{D, k}^{\text {mехо }}$ - частина зовнішньо залежної деструкції ексергії в к-му компоненті, яка спричинена одночасною дією всіх компонентів системи одночасно.

На рис. 1 показана структура розділення деструкції ексергії у k-му компоненті системи у відповідності до наведеної вище класифікації.

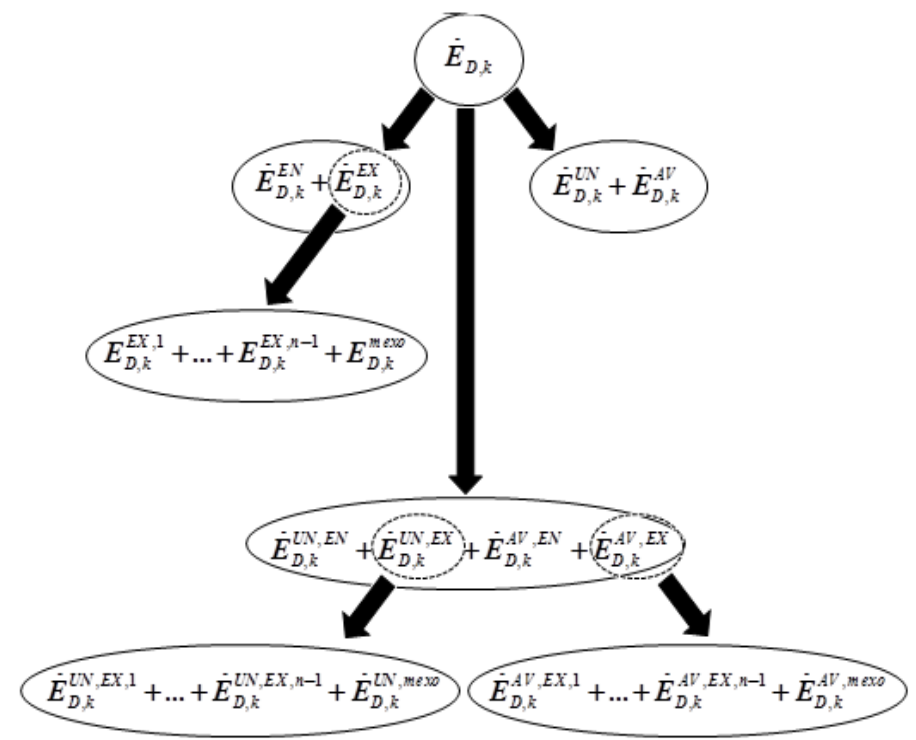

Рис. 1 - Поділ деструкції ексергії у k-му компоненті системи [0] Fig. 1 - Splitting exergy destruction within the k-th component of the system [0]

3 точки зору практичного удосконалення теплоенергетичної системи необхідно виділяти саме ту деструкцію ексергії, яку можна уникнути за рахунок удосконалення k-го елемента. Ця складова буде визначатися за формулою [0]:

$$
E_{D, k}^{A V, \Sigma}=E_{D, k}^{A V, E N}+\sum_{\substack{r=1 \\ r \neq k}}^{n-1} \dot{E}_{D, r}^{A V, E X, k}
$$

де $E_{D, k}^{A V, \Sigma}$ - сумарне значення деструкції ексергії, якої можна позбутися за рахунок термодинамічного удосконалення k-го компонента і яка має місце у даному елементі $E_{D, k}^{A V, E N}$ та інших $r$ - елементах $\sum_{\substack{r=1 \\ r \neq k}}^{n-l} \dot{E}_{D, r}^{A V, E X, k}$.

В даних дослідженнях в якості низькотемпературного джерела енергії використовуються стічні води 3 температурою, що змінюється в діапазоні $13 \ldots 17$ оС. Для проектного режиму охолодження теплоносія проміжного контуру у випарнику прийнято рівним $3 \mathrm{~K}$, у теплообміннику проміжного контуру нагрів цього теплоносія становить 3 К. Мінімальний температурний напір як у випарнику так і у конденсаторі рівний 5 К. Температурний напір у теплообміннику проміжного контуру у проектному режимі становить 7 К.

Для дослідження режимів роботи системи теплозабезпечення при зміні теплового навантаження (непроектний режим роботи) використаний квазістаціонарний підхід побудови математичних моделей відповідно до [0] 3 урахуванням добового коливання параметрів впливу. Для кожного режиму роботи ТНУ ексергія продукту, яка рівна ексергії продукту конденсатора, залишається постійною.

Для реалізації поглибленого ексергетичного аналізу ТНУ використаний так званий термодинамічний метод, який базується на побудові гібридних термодинамічних циклів [0 - 0]. При цьому, для проектного режиму, при визначенні 
деструкції ексергії, яку неможливо позбутися через технологічні обмеження, прийнятий мінімальний температурний напір у випарнику та конденсаторі рівним $1 \mathrm{~K}$, у проміжному теплообміннику 2 К, а ізоентропний ККД компресора - $94 \%$.

На даному етапі досліджень вплив гідравлічних опорів в елементах ТНУ на деструкцію ексергії окремо не вивчався.

Аналіз отриманих даних показав, що частка деструкції ексергії в кожному елементі ТНУ є різною в різні періоди опалювального сезону. Відповідно, на відміну від апробованих на практиці підходів з ексергетичної оцінки ТНУ, де розглядається тільки один режим роботи системи, для адекватної оцінки ТНУ в складі системи теплозабезпечення будинку з урахуванням мінливих режимів роботи пропонується використовувати динамічний метод аналізу на основі квазістаціонарного підходу 3 розрахунковим часовим кроком 24 год із подальшим інтегральним оцінюванням ексергетичних критеріїв за допомогою їх сезонних значень.

На рис. 2 показані сезонні значення внутрішньо залежної і тієї, що можна уникнути, деструкції ексергії $E_{D, k}^{E N, A V, y e a r}$ та зовнішньо залежної і тієї, що можна уникнути, деструкції ексергії $E_{D, k}^{E X, A V, r, y e a r}$ для кожного компонента ТНУ. Причому остання складова у свою чергу розподілена кількісно на ті інші елементи теплового насоса, від яких вона залежить (див. формулу (4)).

Отже, із рис. 2 бачимо, що в компресорі більша половина деструкції ексергії, яку можна уникнути, (496 кВт·год або $76 \%$ ) залежить від термодинамічної досконалості інших елементів. У свою чергу, ця деструкція, в основному обумовлена недосконалістю проміжного теплообмінника та випарника, через що у компресорі має місце 194 кВт·год та 135 кВт·год сезонної деструкції ексергії відповідно. Всього 69 кВт·год сезонної деструкції ексергії у компресорі спричинена конденсатором, а 98 кВт·год - сумісною дією кількох елементів (проміжного теплообмінника, випарника та конденсатора).

Із рис. 2 бачимо, що на відміну від компресора, в конденсаторі майже вся деструкція ексергії, яку можна уникнути, (229 кВт·год або 96 \%) залежить від термодинамічної досконалості самого конденсатора.

Із рис. 2 видно, що у дросельному вентилі вся частина деструкції ексергії, яку можна уникнути, залежить від термодинамічної досконалості інших компонентів ТНУ. Причому, більша частка (162 кВт·год або $35 \%$ даної деструкції спричинена недосконалістю проміжного теплообмінника. 138 кВт·год або 30 \% даної частини деструкції ексергії зумовлена процесами необоротності при передачі теплоти у конденсаторі. 125 кВт·год або 27 \% даної частини деструкції ексергії зумовлена процесами необоротності при передачі теплоти у випарнику. Як видно із рис. 2 частина зовнішньо залежної і тієї, яку можна уникнути, деструкції ексергії у дросельному вентилі, що зумовлена компресором, $\epsilon$ від’ємною (-5 кВт·год). Це означає, що ця частина деструкції ексергії у дросельному вентилі може бути зменшена шляхом збільшення термодинамічної недосконалості у компресорі. Деструкція ексергії, що можна уникнути, і яка обумовлена сумісною дією всіх чотирьох елементів (проміжного теплообмінника, випарника, конденсатора та компресора) рівна 40 кВт·год.

Із рис. 2 видно, що у випарнику майже вся частина деструкції ексергії (277 кВт·год або 90 \%), яку можна уникнути, залежить від термодинамічної досконалості самого випарника. Що ж стосується зовнішньо залежної деструкції ексергії, то найбільша частка, 37 кВт·год, але з від'ємним знаком, обумовлена сумісними процесами необоротності у компресорі, конденсаторі та проміжному теплообміннику. Для зменшення від'ємної частини деструкції ексергії у випарнику необхідно на цю величину збільшити деструкцію ексергії в інших елементах.

Так само як і у конденсаторі та випарнику майже вся частина деструкції ексергії (277 кВт·год або 89 \%), яку можна уникнути, залежить від термодинамічної досконалості самого проміжного теплообмінника.

Отже, як видно із рис. 2, найбільше значення сумарної деструкції ексергії, що можна позбутися у ТНУ за рахунок термодинамічного удосконалення k-го компонента, зосереджене у теплообміннику проміжного контуру $\mathrm{i}$ рівне $E_{D, S W H E}^{A V, \sum \text {,year }}=726$

кВт·год (або близько 40 \%). Для випарника та конденсатора ці частини деструкції ексергії виявилися меншими ніж у теплообміннику проміжного контуру і рівні відповідно 531 кВт·год та 441 кВт·год (або відповідно 29 та 24 \%). Для компресора ця частина деструкції ексергії є досить малою і становить 148 кВт·год (або $8 \%$ ). Тобто у прийнятих умовах, суттєвого термодинамічного удосконалення ТНУ можна досягти за рахунок зниження необоротностей при передачі теплоти в першу чергу у проміжному теплообміннику, у випарнику та конденсаторі - тобто зниження температурного напору у цих теплообмінниках. При цьому, проміжний теплообмінник має більші можливості ніж випарник та конденсатор. У компресорі можливості незначні.

Для додаткового підтвердження правильності висновків на основі запропонованих ключових показників енергетичної ефективності було розраховано значення сезонного коефіцієнта трансформації як відношення сезонної подачі теплоти від ТНУ до сезонного споживання електроенергії ТНУ. Результати розрахунків наведено на рис. 3. Бачимо, що у випадку зниження температурного напору (необоротності) тільки у конденсаторі сезонний коефіцієнт трансформації зріс у порівнянні з базовим (початковим) варіантом ТНУ від 4,28 до 4,63. Якщо зменшити необоротність у випарнику, то коефіцієнт трансформації зростає на більше значення (до 4,75). У випадку підвищення термодинамічної ефективності проміжного теплообмінника шляхом зниження температурного напору у ньому, то у порівнянні з базовим варіантом ТНУ)\сезонний коефіцієнт трансформації зростає від 4,28 до 4,87. 

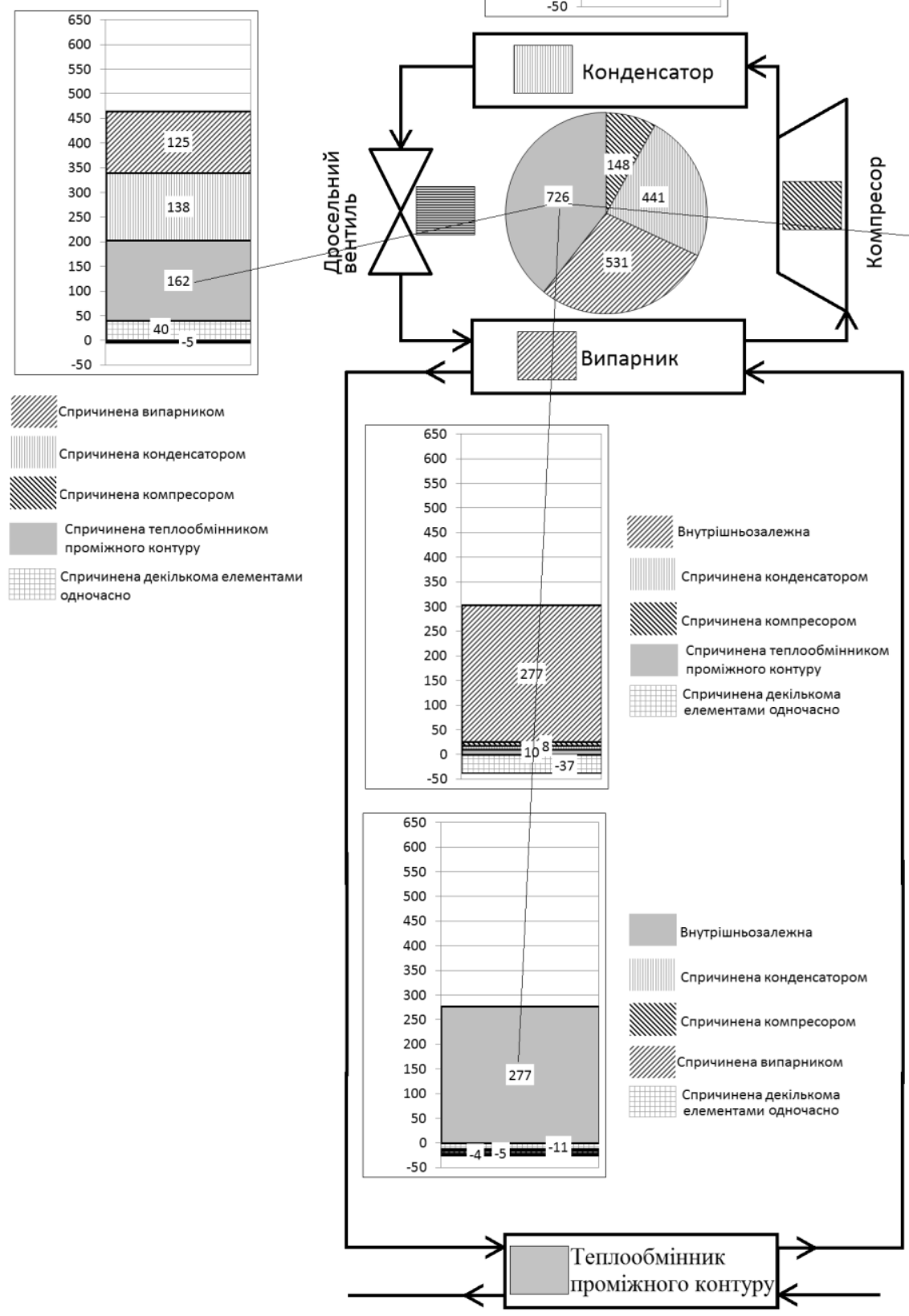

Внутрішньозалежна

Спричинена випарником

Спричинена компресором

Спричинена теплообмінником проміжного контуру Спричинена декількома елементами одночасно
229

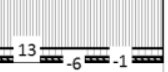

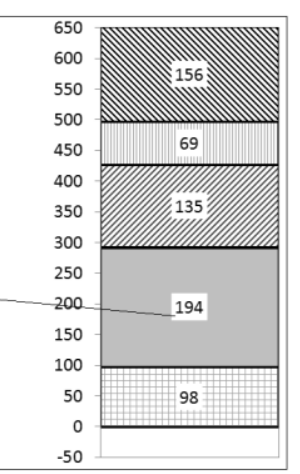

Внутрішньозалежна

Спричинена конденсатором

Спричинена випарником

Спричинена теплообмінником проміжного контуру

Спричинена декількома елементами орночасно

Рис. 2 - Сезонні $E_{D, k}^{A V, \sum, y e a r}$ за опалювальний період значення деструкції ексергії, що можна уникнути за рахунок удосконалення k-го елемента ТНУ типу «вода-вода» на стічних водах

Fig. 2 - Seasonal values of exergy destruction which can be avoided by improving the k-th element of wastewater source heat pump system 
На рис. 4 показано, що підвищення коефіцієнтів трансформації до значень, які наведені на рис. 3, призводить до відчутного зниження сезонного споживання електроенергії у ТНУ. При цьому, найбільшого зниження (до 12\%) досягається саме у випадку підвищення термодинамічної ефективності проміжного теплообмінника. Удосконалення випарника та конденсатора в даному випадку мають менші можливості щодо підвищення енергетичної ефективності ТНУ.

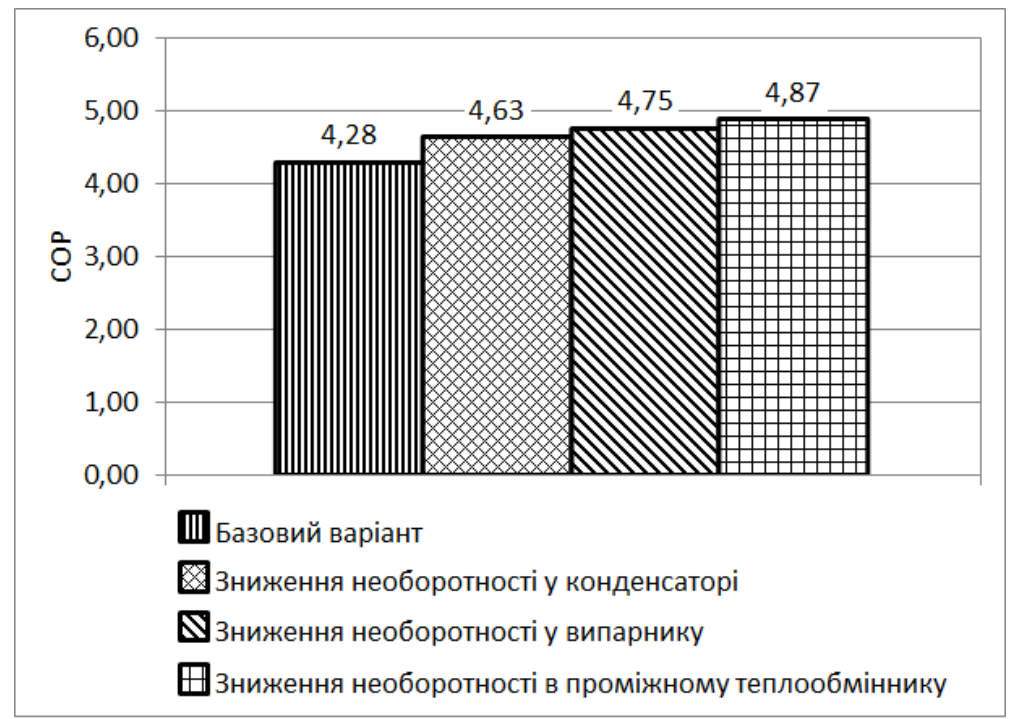

Рис. 3 - Значення сезонного коефіціснта трансформації (СОР) теплонасосної установки для базового варіанту та після зниження необоротностей в окремих ії компонентах

Fig. 3 - Seasonal coefficients of performance of the heat pump system for the base case and after decreasing irreversibility within its components

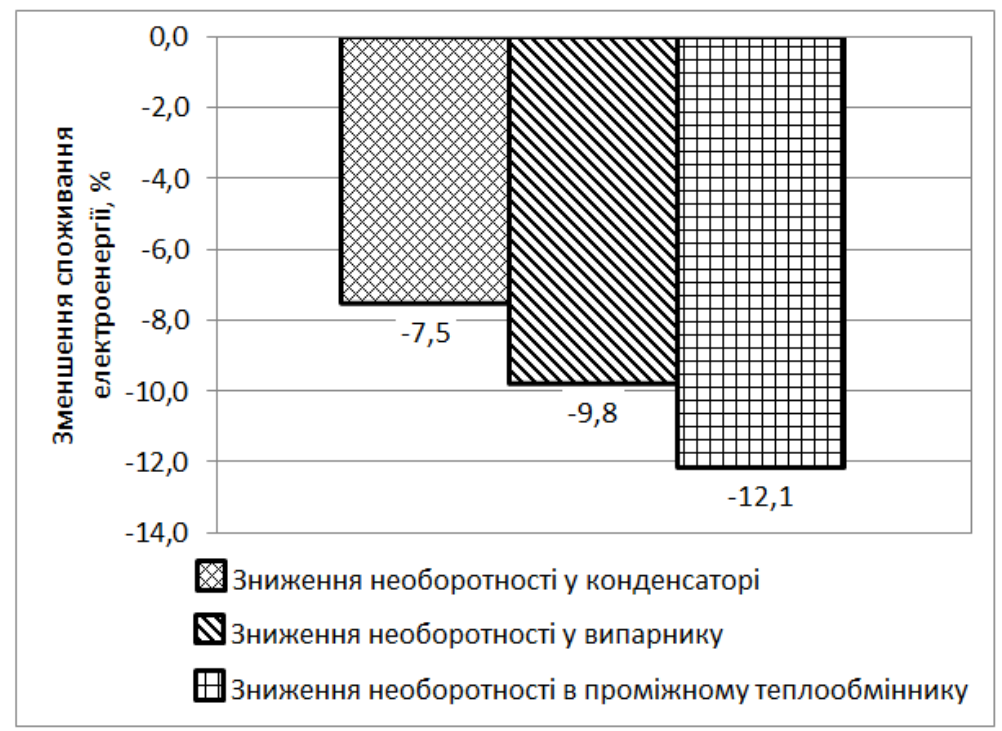

Рис. 4 - Зменшення у порівнянні із базовим варіантом сезонного споживання електроенергії теплонасосною установкою після зниження необоротностей в окремих її компонентах

Fig. 4 - Reduction of seasonal electricity consumption within the heat pump system after decreasing irreversibility within its components in comparison with the base case

\section{Висновки}

1. В роботі наведено та підтверджено доцільність застосування критеріїв поглибленого ексергетичного аналізу (а саме сезонної деструкції ексергії) для оцінювання та обгрунтування рішень 3 підвищення енергетичної ефективності ТНУ на стічних водах, призначеного для теплозабезпечення будівлі протягом опалювального періоду із урахуванням сезонних коливань потреб енергії та температури низькопотенційного джерела. 
http://www.atbp.onaft.edu.ua/

2. Показано, що у прийнятих умовах найбільша частка (близько 40 \%) сезонної деструкції ексергії, якої можна позбутися у ТНУ, спричинена необоротностями в теплообміннику проміжного контуру. Необоротності у випарнику та конденсаторі спричиняють відповідно 29 та 24 \% деструкції ексергії, що можна уникнути. Удосконалення компресора забезпечує всього 8\% зниження сезонної деструкції, що можна позбутися. Все це означає, що для підвищення енергетичної ефективності ТНУ в першу чергу потрібно удосконалювати проміжний теплообмінник.

3. Отриманий на основі критеріїв поглибленого ексергетичного аналізу висновок підтверджено шляхом розрахунку сезонного споживання електроенергії для різних варіантів удосконалення ТНУ. Показано, що саме удосконалення проміжного теплообмінника забезпечує найбільше (до 12\%) зниження сезонного споживання електроенергії.

Подяка. Стаття підготовлена в рамках виконання проекту «Розроблення техніко-технологічних схем та систем керування теплозабезпечення населених пунктів на основі термодинамічних підходів» (номер державної реєстрації НДР 0120U102168).

\section{Список використаних джерел}

[1] Гохштейн Д.П. Современные методы термодинамического анализа энергетических установок / Д.П. Гохштейн. М.: Энергия, 1969. - 368 с.

[2] Tsatsaronis, G. Advanced exergy-based methods used to understand and improve energy-conversion systems/ G. Tsatsaronis, T. Morosuk [Text] // The 4th International Conference on Contemporary Problems of Thermal Engineering (CPOTE-2016). Program and Proceedings, Gliwice - Katowice, Silesia, Poland, September, 14-16, 2016. - Gliwice Katowice, Silesia, 2016. - pp. 75 - 89.

[3] Morosuk T. New approach to the exergy analysis of absorption refrigeration machines [Text] / T. Morosuk, G. Tsatsaronis // Energy. - 2008. - Vol. 33. - pp. 890-907.

[4] Morosuk, T. Advanced exergetic evaluation of refrigeration machines using different working fluids [Text] / T. Morosuk, G. Tsatsaronis // Energy. - 2009. - Vol. 34. - pp. 2248-2258.

[5] Erbay, Z. Application of conventional and advanced exergy analyses to evaluate the performance of a ground-source heat pump (GSHP) dryer used in food drying [Text] / Z. Erbay, A. Hepbasli // Energy Conversion and Management. - 2014. Vol. 78. - pp. 499-507.

[6] Харлампиди, Д. Х. Структурный термодинамический анализ парокомпрессорной холодильной машины [Текст] / Д. Х. Харлампиди, В. А. Тарасова // Технические газы. - 2012. - № 5. - С. 57-66.

[7] Hepbasli, A. A key review of wastewater source heatpump (WWSHP) systems [Text] / A. Hepbasli, E. Biyik, O. Ekren, H. Gunerhan, M. Araz // Energy Conversion and Management. - 2014. -Vol. 88. - pp. 700-722.

[8] Voloshchuk V. A. Advanced exergetic analysis of a heat pump providing space heating in built environment [Text] / V. A. Voloshchuk // Energetika. - 2017. - 63(3). - pp. 83-92.

[9] Herbas, T.B Steady-state simulation of vapor-compression heat pump [Text] / T. B. Herbas, E. C. Berlinck, C. A. T. Uriu, R. P. Marques, J. A. R. Parise // International Journal of Energy Research. - 1993. - Vol. 17. - pp. 801-816.

\section{References}

[1] Hokhshtein D.P. Sovremennyie metodyi termodynamycheskoho analyza enerhetycheskykh ustanovok / D.P. Hokhshtein. M.: Enerhyia, 1969. - 368 p.

[2] Tsatsaronis, G. Advanced exergy-based methods used to understand and improve energy-conversion systems/ G. Tsatsaronis, T. Morosuk [Text] // The 4th International Conference on Contemporary Problems of Thermal Engineering (CPOTE-2016). Program and Proceedings, Gliwice - Katowice, Silesia, Poland, September, 14-16, 2016. - Gliwice Katowice, Silesia, 2016. - pp. 75 - 89.

[3] Morosuk T. New approach to the exergy analysis of absorption refrigeration machines [Text] / T. Morosuk, G. Tsatsaronis // Energy. - 2008. - Vol. 33. - pp. 890-907.

[4] Morosuk, T. Advanced exergetic evaluation of refrigeration machines using different working fluids [Text] / T. Morosuk, G. Tsatsaronis // Energy. - 2009. - Vol. 34. - pp. 2248-2258.

[5] Erbay, Z. Application of conventional and advanced exergy analyses to evaluate the performance of a ground-source heat pump (GSHP) dryer used in food drying [Text] / Z. Erbay, A. Hepbasli // Energy Conversion and Management. - 2014. Vol. 78. - pp. 499-507.

[6] Kharlampydy, D. Kh. Strukturniy termodinamicheskij analiz parokompressornoj holodil'noj mashiny [Text] / D. Kh. Kharlampydy, V. A. Tarasova // Tekhnycheskye hazyi. - 2012. - no.5. - pp. 57-66.

[7] Hepbasli, A. A key review of wastewater source heatpump (WWSHP) systems [Text] / A. Hepbasli, E. Biyik, O. Ekren, H. Gunerhan, M. Araz // Energy Conversion and Management. - 2014. -Vol. 88. - pp. 700-722.

[8] Voloshchuk V. A. Advanced exergetic analysis of a heat pump providing space heating in built environment [Text] / V. A. Voloshchuk // Energetika. - 2017. - 63(3). - pp. 83-92.

[9] Herbas, T.B Steady-state simulation of vapor-compression heat pump [Text] / T. B. Herbas, E. C. Berlinck, C. A. T. Uriu, R. P. Marques, J. A. R. Parise // International Journal of Energy Research. - 1993. - Vol. 17. - pp. 801-816. 